\title{
PENINGKATAN KUALITAS PEMBELAJARAN MELALUI PENERAPAN METODA PEMBELAJARAN YANG TERINTEGRASI (INTEGRATED LESSON LEARNED) DARI MATA KULIAH YANG SERUMPUN
}

\author{
Hermin Werdiningsih ${ }^{1}$, Suzanna Ratih Sari ${ }^{2}$ \\ 1,2 Jurusan Arsitektur Fakultas Teknik, Universitas Diponegoro Semarang \\ Jl. Prof Sudarto SH Tembalang Semarang 50131
}

\begin{abstract}
Abstrak
Metoda pembelajaran di Jurusan Arsitektur Fakultas Teknik Universitas Diponegoro khususnya yang diimplementasikan pada mata kuliah - mata kuliah yang serumpun dapat dikatakan masih belum optimal dalam pencapaian kualitas pemahaman dari peserta didik.

Kondisi tersebut dapat diidentifikasi melalui kegiatan evaluasi dari sistem pembelajaan saat ini yangsecara rutin dilakukan di Laboraturium Desain dan Lingkungan Blnaan. Dari hasil analisis diketahui bahwa hampir $80 \%$ dari keseluruhan mahasiswa yang mengambil mata kuliah yang serumpun belum memiliki kemampuan untuk dapat mengintegrasikan peran antara mata kuliah yang berada dalam rumpun yang sama dalam satu permasalahan nyata. Pemahaman mahasiswa yang partial tersebut di perkuat dengan sistem pemberian tugas yang berbeda dan hanya diberikan pada setiap mata kuliah yang berada dalam satu rumpun.

Guna mengantisipasi permasalahan diatas, dalam penelitian ini akan diteliti satu metoda pembelajaranyang dapat memberikan kemudahan bagi mahasiswa untuk mengintegrasikan hubungan yang kuat antar mata kuliah dalam satu rumpun. Metoda yang akan dicoba diimplementasikan adalah metoda pembelajaran "Integrated Lesson Learned".
\end{abstract}

Kata Kunci: Peningkatan Kualitas ,Metoda pembelajaran, Pembelajaran Yang Terintegrasi

\section{Pendahuluan}

Dosen sebagai staf pendidik dan pengajar merupakan ujung tombak penentu keberhasilan setiap anak didiknya. Hal ini menunjukkan betapa eksisnya peran dosen dalam dunia pendidikan. Dalam upaya membelajarkan mahasiswa, dosen dituntut memiliki multi peran yang dapat menciptakan kondisi belajar mengajar yang efisien, efektif dan optimal. Untuk dapat mengajar efektif, dosen harus mampu meningkatkan kesempatan belajar bagi mahasiswa dan meningkatkan mutu mengajarnya melalui berbagai metoda pembelajaran yang tepat.
Demikian juga dengan pelaksanaan proses pembelajaran dari mata kuliah-mata kuliah yang serumpun dibawah naungan Laboratorium Desain Lingkungan Binaan, metoda pembelajaran yang diterapkan hampir selalu diorientasikan kepada mahasiswa sebagai pusat belajar (student center oriented learning). Mahasiswa dalam hal ini dituntut untuk aktif dalam setiap kegiatan pembelajaran. Keberhasilan proses pembelajaran melalui strategi atau model pembelajaran apapun hanya mungkin terjadi apabila dilakukan oleh dosen secara profesional. Profesionalisme dosen berkaitan dengan peningkatan mutu proses dan hasil belajar dari mata kuliah-mata kuliah yang 
diajarkan. Seperti yang tercantum dalam Peraturan Pemerintah RI Nomor 19 tahun 2005 tentang Standar Nasional Pendidikan yang merupakan usaha pemerintah untuk meningkatkan mutu pendidikan di Indonesia. Pasal 19 tersebut berbunyi : Proses pembelajaran pada satuan pendidikan diselenggarakan secara interaktif, inspiratif, menyenangkan, menantang, memotivasi untuk aktif, kreatif, mandiri sesuai bakat, minat dan perkembangan fisik dan psikologis peserta didik. Selama ini Labotarium Desain dan Lingkungan Binaan juga telah menerapkan metoda pembelajaran yang salah satunya adalah dengan studi lapangan dengan harapan mahasiswa dapat secara optimal melihat, mengamati, memahami, mengevaluasi dan dan memberikan solusi terhadap permasalahan-permasalahan di lapangan sesuai dengan mata kuliah yang diambil. Penerapan metoda ini juga didasarkankan bahwa fokus materi pembelajaran di bawah Laboratorium Desain dan Lingkungan Binaan adalah pada satu kawasan dan lingkungan. Lingkup penelitian ini dibatasi pada mahasiswa sebagai obyek sistem pembelajaran tanpa meninggalkan esensi dosen.

\section{Perumusan Masalah}

Masalah-masalah yang dihadapi mahasiswa berdasarkan pengamatan selama ini pada mata kuliah-mata kuliah yang serumpun di Laboratorium Design dan lingkungan binaan.

a. Mahasiswa kurang menguasai materi kuliah yang terintegrasi di dalam satu rumpun

b. Mahasiswa mengalami kesulitan dalam menganalisis isu, peristiwa, fenomena, permasalahan dari topik studi lapangan ditugaskan c. Pemahaman mahasiswa terhadap mata kuliah- mata kuliah yang serumpun masih parsial

d. Mahasiswa kurang mampu mencermati tuntutan professionalisme dari studi lapangan yang ditugaskan

Permasalahan bagi para dosen pembimbing dalam penyelenggaraan mata kuliah-mata kuliah yang serumpun :

a. Kurangnya koordinasi antara mata kuliahmata kuliah yang serumpun dalam pemberian tugas

b. Tugas untuk studi lapangan masih partial dan tidak terintegrasi satu dengan yang lain

c. Para dosen mengalami kesulitan dalam membuat sistem pemberian tugas yang saling berkaitan satu dengan yang lain

\section{Tujuan penelitian}

a. Meningkatkan penguasaan materi kuliah melalui proses integrated lesson study dari mata kuliah yang serumpun.

b. Memudahkan penyampaian isu, peristiwa, fenomena, masalah, topik yang relevan dengan mata kuliah yang se rumpun secara nyata

c. Memberikan pemahaman mahasiswa akan keterkaitan antar materi yang serumpun

d. Meningkatkan kemampuan mahasiswa dalam mencermati tuntutan profesionalisme yang harus dimiliki mahasiswa dalam mengatasi permasalahan yang terintegrasi secara kuat dari mata kuliah-mata kuliah yang serumpun

\section{Manfaat}

Manfaat dari penerapan metoda Integrated Leasson Learned tersebut adalah :

a. Bagi mahasiswa : akan memudahkan mahasiswa memahami permasalahan 
mata kuliah serumpun dengan lebih comprehensive.

b. Bagi Dosen : pemberian tugas yang terintegrasi akan lebih memudahkan proses evaluasi tugas belajar. Dosen menjadi lebih fokus dan mendokumentasikan kemajuan kerjanya. Dosen juga dapat mempublikasikan dan mendiseminasikan hasil akhir dari Lesson Study bersama mahasiswa bimbingannya.

c. Bagi Pengelola mata kuliah : tugas mata kuliah menjadi lebih simple namun lebih bermakna dan bermanfaat bagi pengembangan ilmu pengetahuan

\section{Metodologi Penelitian}

Penelitian ini merupakan penelitian deskriptif kualitatif, karena dalam penelitian ini mendiskripsikan atau mengungkapkan apa yang ada mengenai kondisi atau keadaan dan semua informasi/data diwujudkan dalam bentuk deskriptif.

Penelitian ini bermaksud mengembangkan perangkat pembelajaran dari mata kuliah-mata kuliah yang serumpun dengan penerapan metode integrated lesson learned. Pengembangan perangkat pembelajaran, dilakukan melalui diskusi, simulasi pada kegiatan lapangan yang diikuti oleh dosen dan mahasiswa. Observasi atau pengamatan secara langsung pada penelitian ini dimaksudkan membuat catatan dari seluruh kegiatan pelaksanaan studi lapangan yang berlangsung selama ini. Pengamatan dilakukan untuk menemukenali respon dari mahasiswa terhadap permasalahan yang muncul di lapangan serta menjelaskan permasalahan yang terjadi secara komprehensive mencakup materi mata kuliahmata kuliah yang serumpun. Beberapa unit informasi yang dibutuhkan terkait dengan pengumpulan data untuk penelitian diatas adalah terkait dengan:'

1. Pelaksanaan studi lapangan selama ini

2. Proses evaluasi dari setiap kegiatan studi lapangan

3. Respon mahasiswa terhadap kegiatan studi lapangan

4. Kemampun analisis terhadap permasalahan-permasalahan yang muncul di lapangan

Pengumpulan data dilakukan dengan teknik wawancara secara langsung dengan dosen dan mahasiswa yang terkait dengan penelitian. Oleh karena sumber data adalah kata-kata dan tindakan yang dimunculkan oleh informan maka peneliti harus memahami informan dan konteks. Wawancara dilakukan dengan dua cara yaitu melalui wawancara bebas mendalam terbuka (indepth interview) dan wawancara berstruktur tertutup. Wawancara bebas mendalam khususnya ditujukan kepada para informan kunci (key informant) yang dalam penelitian ini adalah Dosen dan Mahasiswa.

Data data yang diperoleh baik dari hasil pengamatan dan wawancara (termasuk kuesioner) akan diolah, diklasifikasikan, dikaitkan dengan sumber pustaka yang relevan, serta diimplementasikan sebagai model pembelajaran yang efektif, efisien dan terintegrasi.

\section{Leason Learned}

Lesson Learned merupakan suatu pendekatan peningkatan kualitas pembelajaran yang dilaksanakan oleh guru secara kolaboratif, dengan langkah-langkah pokok merancang pembelajaran untuk mencapai tujuan, melaksanakan pembelajaran, mengamati pelaksanaan pembelajaran tersebut, serta melakukan refleksi untuk mendisukusikan pembelajaran yang dikaji tersebut dan menyempurkannya dan merencanakan 
pembelajaran berikutnya. Fokus utama pelaksanaan Lesson Learned adalah: aktivitas mahasiswa di lapangan terkait dengan mata kuliah yang terintegritas dengan mata kuliah lain yang serumpun, Lesson Learned dilanjutkan dengan praktik supervisi yang dilakukan Dosen Pembimbing sebagai supervisor yang memberikan saran/masukan kepada mahasiswa yang melakukan praktik lapangan, sementara praktik Lesson Learned sepenuhnya dilakukan oleh mahasiswa. Dosen pengampu mata kuliah dari mata kuliah-mata kuliah yang terintegrasi menempatkan diri juga sebagai observer dan reflektor. Setelah seluruh rangkaian Lesson Learned selesai dilakukan, barulah Dosen Pembimbing dari berbagai mata kuliah yang serumpun memposisikan diri sebagai supervisor. Konsep dan praktik Lesson Learned atau lebih dikenal dengan Lesson Study pertama kali dikembangkan oleh para guru pendidikan dasar di Jepang, yang dalam bahasa Jepang-nya disebut dengan istilah kenkyuu jugyo. Adalah Makoto Yoshida, orang yang dianggap berjasa besar dalam mengembangkan kenkyuu jugyo di Jepang. Keberhasilan Jepang dalam mengembangkan Lesson Study tampaknya mulai diikuti pula oleh beberapa negara lain, termasuk di Amerika Serikat yang secara gigih dikembangkan dan dipopulerkan oleh Catherine Lewis yang telah melakukan penelitian tentang Lesson Study di Jepang sejak tahun 1993. Sementara di Indonesia pun saat ini mulai gencar disosialisasikan untuk dijadikan sebagai sebuah model dalam rangka meningkatkan proses pembelajaran siswa, bahkan pada beberapa sekolah sudah mulai dipraktikkan. Meski pada awalnya, Lesson Study dikembangkan pada pendidikan dasar, namun saat ini ada kecenderungan untuk diterapkan pula pada pendidikan menengah dan bahkan pendidikan tinggi.

Lesson Study bukanlah suatu strategi atau metode dalam pembelajaran, tetapi merupakan salah satu upaya pembinaan untuk meningkatkan proses pembelajaran yang dilakukan oleh sekelompok guru secara kolaboratif dan berkesinambungan, dalam merencanakan, melaksanakan, mengobservasi dan melaporkan hasil pembelajaran. Lesson Study bukan sebuah proyek sesaat, tetapi merupakan kegiatan terus menerus yang tiada henti dan merupakan sebuah upaya untuk mengaplikasikan prinsip-prinsip dalam Total Quality Management, yakni memperbaiki proses dan hasil pembelajaran siswa secara terusmenerus, berdasarkan data. Lesson Study merupakan kegiatan yang dapat mendorong terbentuknya sebuah komunitas belajar (learning society) yang secara konsisten dan sistematis melakukan perbaikan diri, baik pada tataran individual maupun manajerial. Slamet Mulyana (2007) memberikan rumusan tentang Lesson Study sebagai salah satu model pembinaan profesi pendidik melalui pengkajian pembelajaran secara kolaboratif dan berkelanjutan berlandaskan pada prinsippsrinsip kolegalitas dan mutual learning untuk membangun komunitas belajar.

Lesson Study sangat efektif bagi guru karena telah memberikan keuntungan dan kesempatan kepada para guru untuk dapat: (1) memikirkan secara lebih teliti lagi tentang tujuan, materi tertentu yang akan dibelajarkan kepada siswa, (2) memikirkan secara mendalam tentang tujuan-tujuan pembelajaran untuk kepentingan masa depan siswa, misalnya tentang arti penting sebuah persahabatan, pengembangan perspektif dan cara berfikir siswa, serta kegandrungan siswa terhadap ilmu pengetahuan, (3) mengkaji 
tentang hal-hal terbaik yang dapat digunakan dalam pembelajaran melalui belajar dari para guru lain (peserta atau partisipan Lesson Study), (4) belajar tentang isi atau materi pelajaran dari guru lain sehingga dapat menambah pengetahuan tentang apa yang harus diberikan kepada siswa, (5) mengembangkan keahlian dalam mengajar, baik pada saat merencanakan pembelajaran maupun selama berlangsungnya kegiatan pembelajaran, (6) membangun kemampuan melalui pembelajaran kolegial, dalam arti para guru bisa saling belajar tentang apa-apa yang dirasakan masih kurang, baik tentang pengetahuan maupun keterampilannya dalam membelajarkan siswa, dan (7) mengembangkan "The Eyes to See Students", dalam arti dengan dihadirkannya para pengamat (obeserver), pengamatan tentang perilaku belajar siswa bisa semakin detail dan jelas.

\section{Tahapan-Tahapan Lesson Study}

Berkenaan dengan tahapan-tahapan dalam Lesson Study ini, dijumpai beberapa pendapat. Menurut Slamet Mulyana (2007) dan konsep Plan-Do-Check-Act (PDCA), di bawah ini akan diuraikan secara ringkas tentang empat tahapan dalam penyelengggaraan Lesson Study.

\section{a. Tahapan Perencanaan (Plan)}

Dalam tahap perencanaan, para guru yang tergabung dalam Lesson Study berkolaborasi untuk menyusun Rencana Pembelajaran yang mencerminkan pembelajaran yang berpusat pada siswa. Perencanaan diawali dengan kegiatan menganalisis kebutuhan dan permasalahan yang dihadapi dalam pembelajaran, seperti tentang: kompetensi dasar, cara membelajarkan siswa, mensiasati kekurangan fasilitas dan sarana belajar, dan sebagainya, sehingga dapat ketahui berbagai kondisi nyata yang akan digunakan untuk kepentingan pembelajaran. Selanjutnya, secara bersama-sama pula dicarikan solusi untuk memecahkan segala permasalahan ditemukan. Kesimpulan dari hasil analisis kebutuhan dan permasalahan menjadi bagian yang harus dipertimbangkan dalam penyusunan Rencana Pembelajaran, sehingga Rencana Pembelajaran menjadi sebuah perencanaan yang benar-benar sangat matang, yang didalamnya sanggup mengantisipasi segala kemungkinan yang akan terjadi selama pelaksanaan pembelajaran berlangsung, baik pada tahap awal, tahap inti sampai dengan tahap akhir pembelajaran.

\section{b. Tahapan Pelaksanaan (Do)}

Pada tahapan yang kedua, terdapat dua kegiatan utama yaitu: (1) kegiatan pelaksanaan pembelajaran yang dilakukan oleh salah seorang guru yang disepakati atau atas permintaan sendiri untuk mempraktikkan Rencana Pembelajaran yang telah disusun bersama, dan (2) kegiatan pengamatan atau observasi yang dilakukan oleh anggota atau komunitas Lesson Study yang lainnya (baca: guru, kepala sekolah, atau pengawas sekolah, atau undangan lainnya yang bertindak sebagai pengamat/observer)

\section{c. Tahapan Refleksi (Check)}

Tahapan ketiga merupakan tahapan yang sangat penting karena upaya perbaikan proses pembelajaran selanjutnya akan bergantung dari ketajaman analisis para perserta berdasarkan pengamatan terhadap pelaksanaan pembelajaran yang telah dilaksanakan. Kegiatan refleksi dilakukan dalam bentuk diskusi yang diikuti seluruh peserta Lesson Study yang dipandu oleh kepala sekolah atau peserta lainnya yang ditunjuk. Diskusi dimulai dari penyampaian kesan-kesan guru yang telah mempraktikkan pembelajaran, dengan 
menyampaikan komentar atau kesan umum maupun kesan khusus atas proses pembelajaran yang dilakukannya, misalnya mengenai kesulitan dan permasalahan yang dirasakan dalam menjalankan Rencana Pembelajaran yang telah disusun.

Selanjutnya, semua pengamat menyampaikan tanggapan atau saran secara bijak terhadap proses pembelajaran yang telah dilaksanakan (bukan terhadap guru yang bersangkutan). Dalam menyampaikan saran-saranya, pengamat harus didukung oleh bukti-bukti yang diperoleh dari hasil pengamatan, tidak berdasarkan opininya. Berbagai pembicaraan yang berkembang dalam diskusi dapat dijadikan umpan balik bagi seluruh peserta untuk kepentingan perbaikan atau peningkatan proses pembelajaran. Oleh karena itu, sebaiknya seluruh peserta pun memiliki catatan-catatan pembicaraan yang berlangsung dalam diskusi.

\section{d. Tahapan Tindak Lanjut (Act)}

Dari hasil refleksi dapat diperoleh sejumlah pengetahuan baru atau keputusan-keputusan penting guna perbaikan dan peningkatan proses pembelajaran, baik pada tataran indiividual, maupun menajerial.

Pada tataran individual, berbagai temuan dan masukan berharga yang disampaikan pada saat diskusi dalam tahapan refleksi (check) tentunya menjadi modal bagi para guru, baik yang bertindak sebagai pengajar maupun observer untuk mengembangkan proses pembelajaran ke arah lebih baik.

Pada tataran manajerial, dengan pelibatan langsung kepala sekolah sebagai peserta Lesson Study, tentunya kepala sekolah akan memperoleh sejumlah masukan yang berharga bagi kepentingan pengembangan manajemen pendidikan di sekolahnya secara keseluruhan.
Kalau selama ini kepala sekolah banyak disibukkan dengan hal-hal di luar pendidikan, dengan keterlibatannya secara langsung dalam Lesson Study, maka dia akan lebih dapat memahami apa yang sesungguhnya dialami oleh guru dan siswanya dalam proses pembelajaran, sehingga diharapkan kepala sekolah dapat semakin lebih fokus lagi untuk mewujudkan dirinya sebagai pemimpin pendidikan di sekolah.

\section{Data dan Analisa}

Pembelajaran integrated (terpadu) merupakan suatu pendekatan dalam pembelajaran yang secara sengaja mengaitkan beberapa aspek baik dalam intra mata kuliah maupun antar mata matakuliah. Dengan adanya pemaduan itu, mahasiswa akan memperoleh pengetahuan dan ketrampilan secara utuh/comprehensive, sehingga pembelajaran menjadi bermakna bagi mahasiswa. Bermakna disini memberikan arti bahwa pada pembelajaran terpadu siswa akan dapat memahami konsep-konsep yang mereka pelajari melalui pengalaman langsung dan nyata yang menghubungkan antar konsep dalam intra mata kuliah maupun antar mata kuliah.

Menurut Fogarty, pembelajaran terpadu tipe integrated (keterpaduan) adalah tipe pembelajaran terpadu yang menggunakan pendekatan antar bidang studi, menggabungkan bidang studi dengan cara menetapkan prioritas kurikuler dan menemukan keterampilan, konsep dan sikap yang saling tumpang tindih dalam beberapa bidang studi (Fogarty, 1991: 76). Lebih lanjut pembelajaran terpadu merupakan pembelajaran yang dipadukan dari konsep, materi, mata pelajaran, bahkan sikap dan perilaku terkait yang dijadikan suatu tema, dan tema-tema tersebut tidak dipilih-pilih antar bidang studi. Oleh karena itu, dalam penelitian ini metode pembelajaran yang akan diterapkan 
adalah tipe pembelajaran terpadu khususnya di dalam pembuatan tugas bersama dari mata kuliah-mata kuliah yang serumpun. Sistem pembelajaran terpadu dapat dilakukan melalui beberapa hal diantaranya adalah dosen terpadu, materi kuliah terpadu ataupun tugas terpadu. Pada penelitian ini dipilih sistem pembelajaran dengan tugas terpadu. Dengan harapan tugas bersama tersebut dapat memperkaya proses pemikiran mahasiswa sekaligus mengajarkan cara penyusunan tugas yang terpadu dan komprehensif.

Berdasarkan pengamatan selama penerapan metoda pembelajaran dengan studi lapangan tersebut, terdapat tiga hal penyebab studi lapangan yang dilaksanakan saat ini di tugas mata kuliah-mata kuliah yang serumpun di bawah Laboratorium Desain dan Lingkungan Binaan dianggap kurang berhasil dan kurang berdampak pada peningkatan mutu pembelajaran mahasiswa: 1) tidak ada konsep perencanaan yang jelas dari kegiatan studi lapangan dan 2) materi studi lapangan tidak berbasis pada permasalahan di dalam mata kuliah-mata kuliah yang serumpun, sehingga seringkali terjadi duplikasi dan kurang fokus, 3). Materi pelatihan, 3) Kurang koordinasi antar pengampu mata kuliah yang serumpun dalam memberikan materi studi lapangan, sehingga mahasiswa belum dapat secara optimal memahami keterkaitan antar mata kuliah yang serumpun secara wholistic. Selama ini mereka hanya memahami mata kuliah secara partial, sehingga ketika harus menyelesaikan permasalahan secara mendalam terkait dengan permasalahan dari mata kuliah- mata kuliah yang serumpun, mahasiswa mengalami kesulitan.

Kegiatan evaluasi yang dilakukan Laboratorium Desain dan Lingkungan Binaan melalui kegiatan pembagian quetioner terkait dengan permasalahan diatas, maka ada beberapa yang mendasari peneliti untuk mengcreate metoda pembelajaran pembuatan tugas lapangan yang lebih baik, lebih terintegritas, lebih efektif dan hasil untuk mahasiswa lebih optimal. Dari hasil questioner yang dilakukan dengan melibatkan dosen dan mahasiswa semester VI keatas dan yang sudah menjalani kuliah di semester IV dan $\mathrm{V}$ dari mata kuliah yang terintegrasi diperoleh informasi bahwa $80 \%$ dosen dari mata kuliah yang terintegrasi menyatakan setuju untuk dibuatkan tugas bersama untuk mata kuliah yang terintegrasi dengan perencanaan pelaksanaan yang direncanakan secara matang. Demikian juga dengan hasil questioner yang dibagikan kepada mahasiswa. Mereka berpendapat bahwa dengan adanya tugas dari mata kuliah yang terintegrasi akan lebih efektif, lebih komprehensif dan lebih terintegrasi. Mahasiswa dalam hal ini juga lebih mudah memahami tugas dari mata kuliah yang serumpun secara utuh tidak partial dan terkadang tumpang tindih antar mata kuliah yang serumpun, mengurangi beban tugas dan mahasiswa dapat lebih fokus dalam mengerjakan tugas.

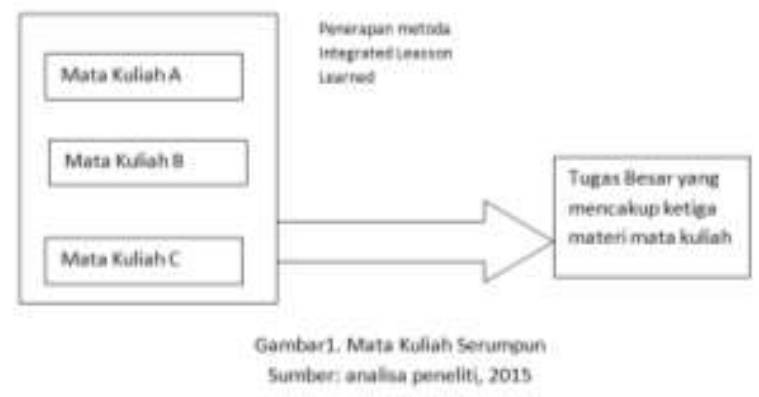

Beberapa mata kuliah yang serumpun yang diintegrasikan dengan metoda pembuatan tugas bersama 


\section{A. Penggabungan Macam Mata kuliah}

Berdasarkan Kurikulum 2007-2012 Jurusan Arsitektur FT Undip (lampiran)

Ada beberapa mata kuliah yang dapat dieffisiensikan dalam tiap semester yaitu dengan penggabungan antara mata kuliah yang serumpun dalam semester yang sama dalam lingkup Laboratorium Desain Lingkungan Binaan diantaranya adalah

1. Semester 4 yaitu:

- Mata kuliah Arsitektur Lingkungan 2

- Perencanaan Dan Perancangan Tapak

2. Semester 5 yaitu:

- Perancangan Permukiman 1

- Perencanaan Perancangan Tapak dan Lansekap

3. Semester 6 yaitu:

- Perancangan Permukiman 2

- Mata Kuliah Pilihan

4. Semester 7 yaitu:

- Perancangan Kota 2

- Arsitektur Lansekap Lanjut.

Penggabungan 2 mata kuliah atau lebih didasarkan pada kedudukan dalam Kurikulum sehingga memudahkan untuk proses belajar mengajar dan evaluasi yang dilakukan dengan sistem komputer dalam SIA. Hal ini didukung dengan hasil kuisioner dari 25 responden, 23 menyatakan setuju (92\%), dengan alasan :

- Lebih ringan dan efisien dalam survei

- Substansi hampir sama jadi berfikir menyeluruh

- Jumlah tugas lebih sedikit

Dan 8 \% (2 responden) menyatakan tidak setuju, dengan alasan:

- Tidak minat pada matakuliah kawasan

- Antara tugas mata kuliah tidak fokus, membingungkan jadi bisa tumpang tindih

- Kekhawatiran koordinasi masing-masing dosen mata kuliah tidak berjalan dengan baik terutama yang hanya mengambil 1 mata kuliah, sehingga merugikan mahasiswa.

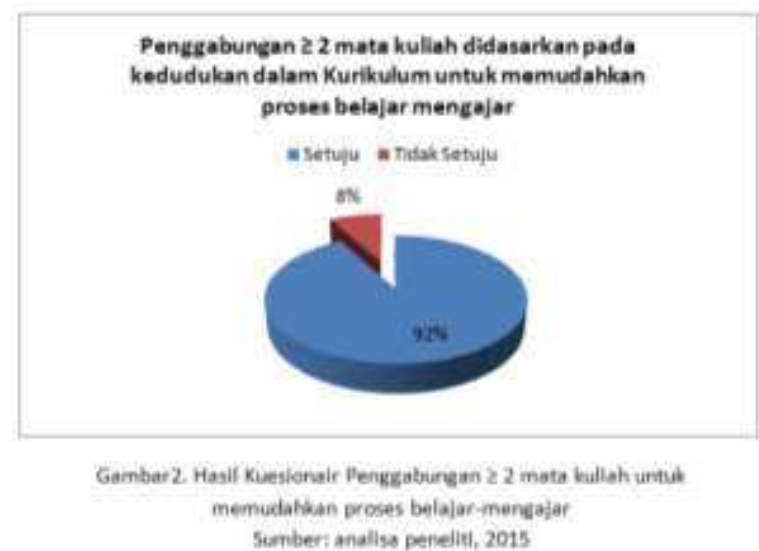

\section{B. Materi Tugas}

Substansi materi tugas didasarkan kesamaan dan kemiripan baik lingkup maupun penerapannya sesuai dengan standart kompetensi yang tertuang dalam GBPP masing-masing mata kuliah (GBPP terlampir ) yang terinci dalam SAP, seperti contoh :

\section{Mata Kuliah Arsitektur Lingkungan 2 dan Perencanaan dan Perancangan Tapak}

Standart Kompetensi dari Mata KuliahArsitektur Lingkungan 2 dan Perencanaan dan Perancangan Tapak:

Yaitu diharapkan pada akhir perkuliahan mahasiswa dapat memahami dan mengkritisi ruang lingkup arsitektur dan lingkungan, penerapan rancangan arsitektur yang berwawasan lingkungan dengan mempertimbangkan potensi alam dan menerapkannya dalam desain dengan menggunakan kaidah-kaidah lansekap skala mikro

Sebagai contoh tugas adalah Contoh topik tugas dimaksud misalnya membahas rancangan tapak dengan kontur miring, MK Arsitektur dan Lingkungan 2 substansinya pada aspek ekologi 
dan pelestarian tapak, sedangkan MK Perenc. dan Perancangan Tapak subtansinya pada treatment bentuk tapak yang fungsional tanpa cut and fill namun tetap memperhatikan aspek pelestarian tapak.

2. Mata kuliah Perancangan Permukiman 1 Perencanaan Perancangan Tapak dan Lansekap

Standart Kompetensi yang diharapkan pada akhir perkuliahan, mahasiswa diharapkan mampu memahami dan menjelaskan beberapa metoda pendekatan untuk pemecahan masalah permukiman dalam suatu kawasan atau wilayah yang merupakan kawasan/wilayah lama maupun baru, serta keterkaitannya dengan kebijakan yang diberlakukan oleh pemerintah yang tentu saja tidak meninggalkan kaidah perancangan tapak sebagai wadah bermukim yang sesuai dengan sosial budaya penghuni.

Contoh topik tugas dimaksud misalnya membahas evaluasi permukiman skala kecilsedang, MK Perancangan Permukiman 1 substansinya pada aspek perancangan permukiman skala kecil-sedang berdasarkan hasil evaluasi dengan mempertimbangkan kaidah dan standar yang berlaku, sedangkan MK Perencanaan Perancangan Tapak dan lanskap subtansinya pada mengisi bagian dari perancangan permukiman tersebut misal bagaimana membuat tapak perumahan yang ideal serta perancangan Ruang Terbuka Hijau (open space, taman, halaman rumah, boulevard, dsb).

\section{Perancangan Permukiman 2 dan Mata Kuliah Pilihan}

Standart kompetensi mata kuliah Perancangan Permukiman 2 pada akhir perkuliahan, mahasiswa diharapkan mampu menyusun perencanaan dan perancangan permukiman kumuh legal yang berkelanjutan dalam skala kawasan kelurahan.

Hal ini dapat dikuatkan dengan pemahaman tugas dari mata kuliah pilihan seperti:

- Konstruksi Bangunan Tradiasional

- Pelestarian arsitektur

- Arsitektur Tropis

- Arsitektur Pedesaan

\section{Perancangan Kota 2 dan Arsitektur Lansekap Lanjut}

Standart kompetensi: pada akhir perkuliahan mahasiswa mampu menguasai seni memecahkan permasalahan ruang perkotaan secara tiga dimensional.

Pemahaman Mata Kuliah Perancangan Kota 2 dapat dikuatkan dengan tugas yang terintegrasi dengan mata kuliah Pilihan pilihan seperti :

- Arsitektur Lansekap lanjut

- Universal desain

- Arsitektur Tropis

Hasil kuisioner menunjukkan bahwa hanya 1 responden (4 \%) yang tidak setuju dengan alasan:

Kekhawatiran mahasiswa untuk yang mengambil hanya 1 mata kuliah justru tugasnya akan terlalu besar.

Sedangkan 96 \% (24 responden) menyatakan setuju.

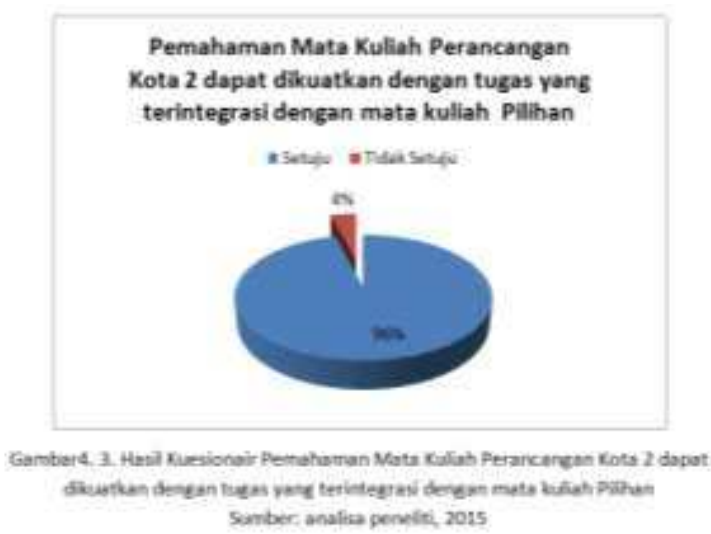


Dari hasil survei Metoda ini diharapkan akan lebih memudahkan mahasiswa untuk memahami sekaligus menganalisis kasus nyata terkait mata kuliah-mata kuliah yang serumpun dengan lebih jelas, lebih detail dan terintegrasi. Sementara bagi mereka yang menyatakan tidak setuju, ada beberapa pertimbangan yang diungkapkan terkait dengan kelemahan-kelemahan dari metode pembelajaran melalui tugas terpadu tersebut. Diantaranya, seperti yang telah diungkap di bab III tentang kelebihan dan kelemahan metode pembelajaran terpadu yakni kesiapan dosen dan mahasiswa dalam mengikuti pola tugas yang terintegrasi. Selain itu dibutuhkan sistem penilaian untuk masingmasing mata kuliah agar bisa lebih efektif dan lebih objektif. Permasalahan juga muncul terkait dengan kontroling dari masing-masing dosen pengampu terhadap pelaksanaan penyusunan tugas terpadu di lapangan. Terkait dengan jumlah mahasiswa yang cukup banyak karena merupakan gabungan dari beberapa mata kuliah serumpun maka perlu dipikirkan tentang pelaksanaan penyusunan tugas terpadu di lapangan.

Berdasarkan dari masukan dosen dan mahasiswa diatas maka peneliti mencoba untuk mengantisipasi kemungkinan permasalahan yang muncul tersebut dengan merencanakan sistem pelaksanaan penyusunan tugas terpadu yang disepakati dan mengandung unsurunsur/elemen-elemen penilaian dari mata kuliah-mata kuliah yang masuk dalam 1 rumpun yang sama, sistem penilaian yang dibuat secara partial sesuai dengan elemen-elemen penilaian yang diharapkan dari masing-masing mata kuliah dan sistem pelaksanaan penyusunan tugas terpadu yang juga didisain secara terpadu dengan melibatkan masing-masing dosen pengampu. Sementara untuk mengantisipasi terjadinya permasalahan terkait dengan pelaksanaan penyusunan tugas terpadu, maka peneliti merencanakan untuk pelaksanaan tetap dilaksanakan dengan jadwal kuliah dari masingmasing mata kuliah hanya penyusunan tugasnya saja yang dilakukan secara bersama. Bagi mahasiswa yang hanya mengikuti satu atau beberapa mata kuliah yang serumpun, maka mahasiswa akan diarahkan untuk menyelesaikan tugasnya sesuai dengan mata kuliah yang diambil.

Penyusunan SAP dilakukan secara kolaboratif dari masing-masing mata kuliah yang serumpun untuk mensinergikan materi kuliah yang akan diberikan kepada mahasiswa. Dengan demikian beban tugas dari masing-masing mata kuliah bisa seimbang dan proporsional sehingga tidak saling mendominasi.

\section{Kesimpulan}

Laboratorium desain Lingkungan Binaan mewadahi beberapa mata kuliah dengan kasus lapangan atau pengamatan lingkup lingkungan, kawasan dan kota yang meliputi sekumpulan bangunan, dengan sistem pembelajaran yang digabungkan atau terintegrasi beberapa mata kuliah yang serumpun menghasilkan:

1. Lebih efektif baik untuk mahasiswa maupun dosen dari segi:

- Waktu

a. Mahasiswa penyelesaian tugas yang jumlahnya lebih sedikit, konsultasi lebih singkat.

b. Dosen, waktu konsultasi, evaluasi untuk mahasiswa yang lebih singkat

- Biaya, terutama bagi mahasiswa karena biaya pembuatan laporan, survei lebih sedikit

- TOR atau panduan penugasan lebih singkat 
2. Perekayasaan analisa mahasiswa lebih lengkap karena dari masing-masing mata kuliah saling menguatkan atau melengkapi.

Untuk mencapai kelengkapan dan kesempurnaan dari tujuan penelitian diperlukan beberapa langkah :

- Perlunya sosialisasi

- Koordinasi antara pengampu mata kuliah

- Persiapan materi perkuliahan, jadwal, TOR tugas yang terintegrasi,

- Sistem Evaluasi dan penilaian

- Perlu koordinasi dengan mata kuliah utama yaitu PA agar hasil gabungan tersebut langsung dapat mendukung mata kuliah tersebut.

Direkomendasikan untuk dapat menindak lanjuti penelitian ini dengan pengelolaan sistem pembelajaran dari dosen.

\section{Daftar Pustaka}

Bill Cerbin \& Bryan Kopp. A Brief Introduction to College Lesson Study. Lesson Study Project. online: http ://www.uwlax.edu/sotl/lsp/index2.htm

Catherine Lewis (2004) Does Lesson Study Have a Future in the United States?. Online: sowi-online.de/journal/2004-

1/lesson_lewis.htm

Lesson Study Research Group online: tc.edu/lessonstudy/whatislessonstudy.ht $\mathrm{ml}$

Slamet Mulyana. 2007. Lesson Study (Makalah). Kuningan: LPMP-Jawa Barat

Wikipedia.2007. Lesson Study. en.wikipedia.org/wiki/Lesson_study 
